\title{
Expression and functional validation of heat-labile enterotoxin B (LTB) and cholera toxin B (CTB) subunits in transgenic rice (Oryza sativa)
}

\author{
Ho Seob Soh' , Ha Young Chung ${ }^{2}$, Hyun Ho Lee ${ }^{3}$, Hemavathi Ajjappala², Kyoungok Jang ${ }^{3}$, Jong-Hwa Park ${ }^{3}$, \\ Joon-Soo Sim², Gee Young Lee ${ }^{1}$, Hyun Ju Lee ${ }^{1}$, Young Hee Han¹, Jae Wook Lim', Inchan Choi ${ }^{2}$, In Sik Chung ${ }^{3}$ \\ and Bum-Soo Hahn ${ }^{2 *}$
}

\begin{abstract}
We expressed the heat-labile enterotoxin B (LTB) subunit from enterotoxigenic Escherichia coli and the cholera toxin B (CTB) subunit from Vibrio cholerae under the control of the rice (Oryza sativa) globulin (G/b) promoter. Binding of recombinant LTB and CTB proteins was confirmed based on $G_{M 1}$-ganglioside binding enzyme-linked immunosorbent assays ( $G_{M 1}$-ELISA). Real-time PCR of three generations $\left(T_{3}, T_{4}\right.$, and $T_{5}$ ) in homozygous lines ( $\left.L C l-11\right)$ showed single copies of $L T B, C T B$, bar and Tnos. $L T B$ and CTB proteins in rice transgenic lines were detected by Western blot analysis. Immunogenicity trials of rice-derived CTB and LTB antigens were evaluated through oral and intraperitoneal administration in mice, respectively. The results revealed that LTB- and CTB-specific lgG levels were enhanced in the sera of intraperitoneally immunized mice. Similarly, the toxin-neutralizing activity of CTB and LTB in serum of orally immunized mice was associated with elevated levels of both $\lg G$ and $\lg A$. The results of the present study suggest that the combined expression of CTB and LTB proteins can be utilized to produce vaccines against enterotoxigenic strains of Escherichia coli and Vibrio cholera, for the prevention of diarrhea.
\end{abstract}

Keywords: Oryza sativa; Enterotoxin; Transgenic plant; Oral vaccine; Immunogenicity

\section{Background}

Enterotoxigenic Escherichia coli (ETEC) and Vibrio cholerae cause diarrhea by colonizing the small intestine and producing enterotoxins. The heat-labile enterotoxin $\mathrm{B}$ (LTB) produced by E. coli and the cholera toxin B subunit (CTB) produced by Vibrio cholerae are similar in structure, function and immunogenicity. LTB and CTB comprise a 27-kDa A subunit with ADP ribosyl transferase activity and a pentamer of 11.6-kDa B-binding subunits. The LTB and CTB subunits bind to $\mathrm{G}_{\mathrm{M} 1}$-ganglioside (galactosyl-N-acetylgalactosamyl-syalil-galactosylglucosylceramide) receptors on intestinal epithelial cells. Binding of LTB and CTB subunits allows a portion of the toxic A subunit to enter the cytosol, initiating a series of cellular events leading to diarrhea (Williams et al. 1999). CTB is

\footnotetext{
* Correspondence: bshahn@korea.kr

${ }^{2}$ Department of Agricultural Biotechnology, National Academy of Agricultural Science, Nongsaengmyeong-ro 370, Jeonju-si, Jeollabuk-do 560-550, South Korea

Full list of author information is available at the end of the article
}

applied as an oral vaccine against cholera, and immune responses against CTB are thought to prevent the toxic A subunit from entering host cells (Clemens et al. 1991). LTB forms a $60-\mathrm{kDa}$ pentamer that facilitates binding to the $\mathrm{G}_{\mathrm{M} 1}$-ganglioside receptors on host epithelial cells, allowing the LTA (heat-labile enterotoxin A subunit) to endocytose and cause toxicity (Mason et al. 1998).

The production of recombinant proteins, such as biopharmaceuticals and vaccines, is commonly performed using bacterial, yeast and mammalian cell expression systems (Wurm 2004; Sue et al. 2005; Terpe 2006; Chen 2012; Mattanovich et al. 2012; Tingfeng et al. 2013). Recombinant proteins used in vaccines are glycosylated; bacteria do not glycosylate proteins, while yeasts may hyper-glycosylate proteins and show poor expression (Prokop et al. 1991; Archer 1994; Harashima 1994). The production of vaccines in microorganisms requires large-scale fermenters and stringent purification steps to obtain sufficient amounts of recombinant protein (Schonberger et al. 1991; Lebens et al. 1993). Similarly, 
mammalian cell cultures are expensive, hindering production of large quantities of vaccines. The development of various plant expression systems has enabled the expression of foreign antigens in plant tissue as edible vaccine vehicles (Haq et al. 1995; Du et al. 2005; El Adab et al. 2007; Ko et al. 2009; Sim et al. 2009; Unni and Soniya 2010; Cui et al. 2011; Guo et al. 2012). Plantbased edible vaccines offer advantages of longer shelflife, stability at room temperature without loss of immunogenicity, and reduced production costs (Streatfield et al. 2001). Plant systems also ensure correct protein folding and eukaryotic post-translational modifications, with relatively high protein yield compared with other expression systems. Recently, enterotoxins have been expressed in several plant species. CTB has been expressed in a number of plant species, including potato (Arakawa et al. 1997), tomato (Jani et al. 2002), tobacco (Jani et al. 2004), carrot (Kim et al. 2009), rice (Oszvald et al. 2008; Kajiura et al. 2013), and maize (Karaman et al. 2012). Similarly, LTB was expressed in transgenic tobacco (Kang et al. 2003; Kim et al. 2011), rice callus (Kim et al. 2010) and carrot (Rosales-Mendoza et al. 2007, 2008), including the hairy roots of Solanaceous species (Guzman et al. 2011), and transgenic lettuce (Kim et al. 2007). However, the majority of plant expression systems pose challenges for vaccine production. For example, the production of vaccines in tobacco requires costly purification processes due to the presence of toxic alkaloid by-products (Ma et al. 2003).

The production of edible vaccines in seeds is attractive due to accumulation of storage proteins in relatively small volumes, and provision of stable dry environments that allow a high level of recombinant protein production. The advantages of rice include the high grain yield, ease of transformation, high stability, and ease of scaleup. Furthermore, rice is a self-pollinating plant with a low risk of unintended gene flow. Studies on rice as bioreactors have focused on utilizing its potential as an efficient oral vaccine delivery system (Yang et al. 2008). To date, several researchers have reported use of rice seed for the production of CTB (Nochi et al. 2007; Kajiura et al. 2013; Yuki et al. 2013).

Serum from CTB-immunized individuals does not neutralize LT as effectively as it neutralizes CT, and LTB and CTB show significant immunological cross-reactivity (Ahrén et al. 1993). Many studies suggested that the combined expression of CTB and LTB would be an excellent option to induce the individual's immunization against ETEC and $V$. cholera because of the similar mechanism of action of CTB and LTB (Svennerholm et al. 1983; Svennerholm et al. 1986; Lebens et al. 1996). Despite the importance, there were no reports available on the combined expression of CTB and LTB proteins in rice. Hence, in the present study, CTB and LTB were produced together in rice grains using recombinant DNA technology. The CTB and $L T B$ transgene expression level was monitored from third to fifth generations $\left(T_{3}-T_{5}\right)$, and the in vivo immunogenicity of rice-derived CTB and LTB was evaluated in mice following oral and intraperitoneal administration. Our findings support the fact that the combined expression of CTB and LTB proteins can be utilized in producing vaccines against ETEC and $V$. cholera to treat diarrhea.

\section{Results}

\section{Vector construction}

The pMJ103 vector integrates the genes $L T B$ and CTB in the inverted repeat regions through homologous recombination (Figure 1). The vector containing LTB and $C T B$ genes is driven by the constitutive globulin promoter $(G l b)$, along with potato protease inhibitor II terminator (Pin II). The expression vector contained the $L T B$ and $C T B$ genes, and the vector was labeled pMJ103-LTB-CTB (Figure 1). The LTB and CTB gene insertions were confirmed based on digestion of the vector with NotI. The digestion yielded about $3 \mathrm{~kb}$ of between the CTB inserts and Pin II (data not shown).

\section{Transformation and analysis of third-generation homozy- gous transgenic rice}

Transformation in rice was performed using an Agrobacterium-mediated method. Putative transgenic calli were selected on MS media containing basta herbicide. The basta-selected calli regenerated into shoots and roots. A total of 25 putative transgenic rice plants was further screened for the presence of the $L T B, C T B$, and bar genes, and plants were designated $\mathrm{T}_{0}$. All 25 transgenic rice plants contained the $L T B, C T B$, and bar genes, based on PCR (Figure 2a). Insertion of the genes encoding the LTB and CTB genes was analyzed via PCR. PCR of transgenic rice plants revealed the expected 217- and 292-bp sequences, respectively (Figure 2a). Similarly, the 
(a)

Transgenic lines

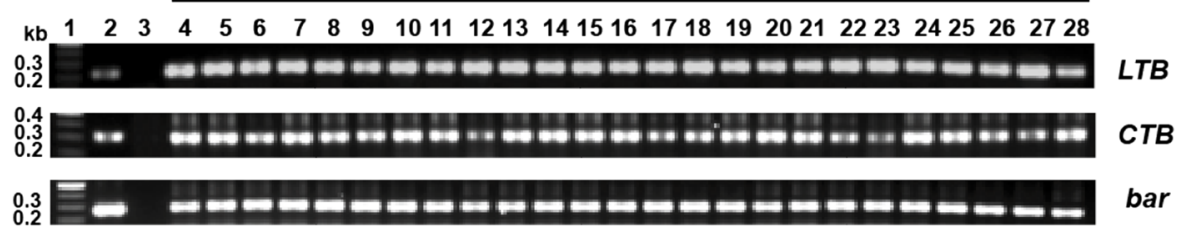

(b)

Transgenic lines

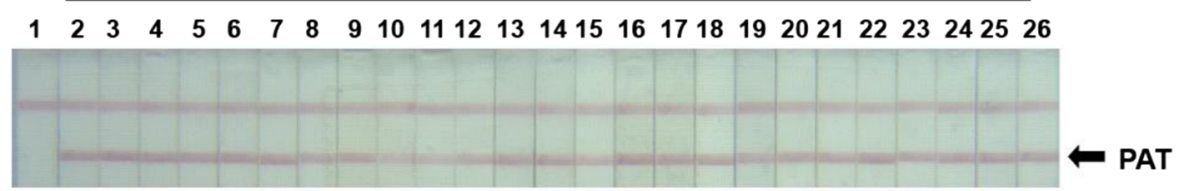

(c)

Transgenic lines

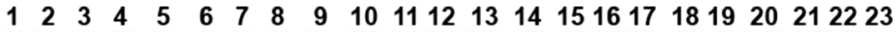

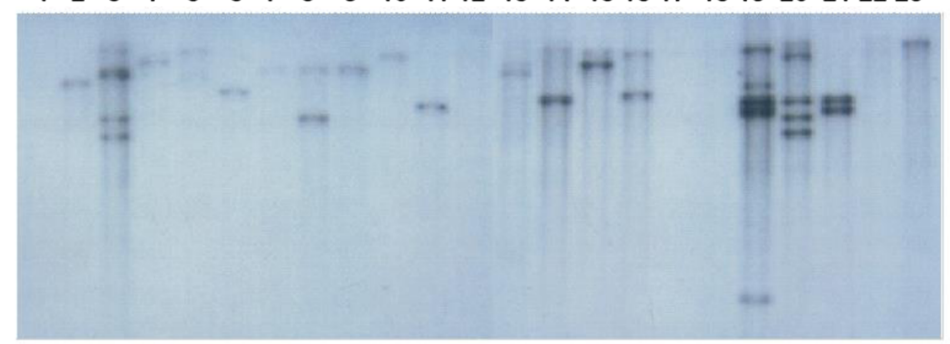

(d)

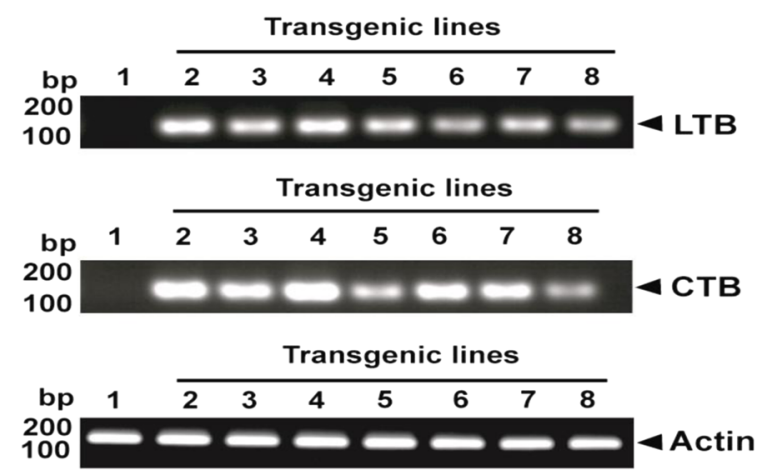

Figure 2 Detection of $\angle T B, C T B$ and bar genes and phosphoacetyl transferase (PAT) in putative transgenic plant leaf tissues. (a) PCR amplification of LTB (217 bp), CTB (292 bp) and bar (302 bp) from transgenic rice genomic DNA. Lane 1 is the size marker. Lane 2 is the binary vector (pMJ103-LTB-CTB). Lane 3 is the wild-type. Lanes 4-28 are transgenic rice plants. (b) Lateral flow assay using the Trait LL lateral flow test kit (Strategic diagnostics). Lane 1 is the wild-type. Lanes 2-26 are transgenic rice plants. (c) Southern hybridization analysis of chromosomal DNA in transgenic rice. Genomic DNA from wild-type untransformed or independent transgenic rice $T_{0}$ lines carrying the pMJ103-LTB-CTB construct was hybridized with a probe specific for the LTB coding region. A total of $10 \mu \mathrm{g}$ of total leaf genomic DNA from transgenic rice plants was digested with Xhol, which cuts at a single site within the binary vector pMJ103-LTB-CTB. (d) LTB and CTB gene transcripts in transgenic plants were detected by RT-PCR. Plant RNA was isolated from selected transgenic plant rice seeds and RT-PCR was performed using a primer pair that specifically amplified 107- and 111-bp DNA fragments of the LTB and CTB genes (lanes 2 to 8). Lane 1 shows the RNA of non-transgenic plants used as a negative control.

transgenic plants were analyzed for PAT protein expression. Phosphoacetyl transferase (PAT) protein-specific band was detected in all 25 transgenic rice plants (Figure 2b). Transgenic plants regenerated from these events were subjected to Southern analysis using DNA obtained from young leaves of 22 lines, which revealed the specific integration of LTB (Figure 2c). Of the 22 plants, 3 were negative for copy number. Nine of twenty-two events involved a single copy number transgene insertion, and 9 of 22 involved multiple copy number transgene insertions.

RT-PCR analysis revealed LTB- and CTB-specific transcripts in total RNA extracted from transformed rice seeds (Figure. 2d). The amplification products corresponded to a specific major transcript of the expected 
size of the transgene (lanes 2 to 8 ). No bands were observed for PCR products of untransformed plants used as negative controls (lane 1). The internal control was actin-1, with a PCR product of $150 \mathrm{bp}$.

Analysis of left and right border chromosomal T-DNA localization in the transgenic lines showed the insertion of a T-DNA region. The localization of T-DNA ranged from chromosome number 1 to 12 with varying chromosomal sizes. The gene was found to be inserted in transgenic lines in the intron, exon, and intergenic regions, respectively (Table 1). Furthermore, the homozygous transgenic $\mathrm{T}_{3}$ lines (LCI-7 and LCI-11) analyzed by genomic DNA PCR revealed left border and right border sequences of $L T B$ and $C T B$ genes (Figure $3 \mathrm{a}, \mathrm{b})$. The results revealed a single band, indicative of homozygous lines (Figure 3a). The transgenic plants were grown to maturity to obtain the first- to fifth-generations $\left(\mathrm{T}_{1-5}\right)$ seeds.

\section{Molecular analysis of third- to fifth- generations $\left(T_{3-5}\right)$ plants}

Three transgenic $\left(\mathrm{T}_{3}, \mathrm{~T}_{4}\right.$ and $\mathrm{T}_{5}$ generations) lines obtained from $\mathrm{T}_{2}$ LCI-7 and LCI-11 transgenic plants were subjected to PCR to detect $L T B, C T B$, and bar; real-time PCR analysis was used to determine the copy number. PCR analysis revealed $L T B, C T B$, bar, and the Tnos terminator (Figure 4a). LTB, CTB, bar, and the Tnos terminator in the transgenic lines from three generations
$\left(\mathrm{T}_{3}, \mathrm{~T}_{4}\right.$ and $\mathrm{T}_{5}$ generations) derived from the LCI-11 line were present as single copies, whereas no copies were detected in the control line (Figure $4 \mathrm{~b}$ ).

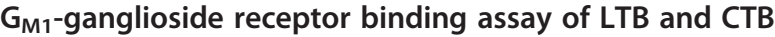 proteins}

Expression levels of LTB and CTB protein in seeds from the $\mathrm{T}_{5}$ transgenic line LCI-11 were determined based on ganglioside-dependent ELISA. The LTB protein accounted for $3.4 \mathrm{ng} \mathrm{gg}^{-1}$ of the total soluble protein and СТВ accounted for $21.3 \mathrm{ng}^{\mathrm{Ng}} \mathrm{g}^{-1}$ of the total soluble protein compared to E. coli-synthesized LTB and CTB (Figure 5a). Because LTB and CTB show significant immunological cross-reactivity (data not shown), the concentration of LTB and CTB found in this study may vary from the actual concentration of LTB and CTB present in the transgenic rice seeds. The expression levels of LTB protein correlated with the single copy number obtained by Southern analysis. Furthermore, CTB and LTB protein expression was detected in the transgenic lines by Western blotting. Therefore, transgenic LCI-11 showed a band of $55 \mathrm{kDa}$, representing the LTB and CTB proteins (Figure $5 b$ ).

\section{LTB- and CTB-specific serum and feces IgG and IgA levels after mouse immunization}

To determine whether the LTB and CTB proteins induced immune responses in mice, we administered LTB

Table 1 Characteristics of transgenic rice lines

\begin{tabular}{|c|c|c|c|c|c|c|c|c|c|c|}
\hline \multicolumn{2}{|c|}{ Event ID } & \multirow{2}{*}{$\begin{array}{l}\text { IPCR prod. } \\
302\end{array}$} & \multirow{2}{*}{$\begin{array}{l}\text { Rice Seq. } \\
302\end{array}$} & \multirow{2}{*}{$\begin{array}{l}\text { No Chr. } \\
3\end{array}$} & \multirow{2}{*}{$\begin{array}{l}\text { Chr. From }{ }^{\#} \\
35,147,954\end{array}$} & \multirow{2}{*}{$\begin{array}{l}\text { Chr. To" } \\
35,147,653\end{array}$} & \multirow{2}{*}{$\begin{array}{l}\text { T-DNA end } \\
-1\end{array}$} & \multirow{2}{*}{$\begin{array}{l}\text { Adaptor start } \\
303\end{array}$} & \multirow{2}{*}{$\begin{array}{l}\text { Copy number } \\
2\end{array}$} & \multirow{2}{*}{$\begin{array}{l}\text { Gene insert } \\
\text { n.d }\end{array}$} \\
\hline LCl-1 & $L^{*}$ & & & & & & & & & \\
\hline & $\mathrm{R}^{*}$ & 482 & 405 & 5 & $24,625,335$ & $24,624,931$ & 72 & 483 & & \\
\hline LCl-3 & $\mathrm{R}$ & 542 & 536 & 8 & $26,724,580$ & $26,724,045$ & -1 & -1 & 1 & intron \\
\hline LCl-4 & $\mathrm{R}$ & 623 & 552 & 7 & $4,833,382$ & $4,832,831$ & 73 & 624 & 2 & n.d \\
\hline \multirow[t]{2}{*}{ LCl-5 } & L & 149 & 150 & 3 & $31,727,379$ & $31,727,528$ & -1 & 150 & 1 & exon \\
\hline & $R$ & 448 & 343 & 3 & $31,727,348$ & $31,727,006$ & 67 & 449 & & \\
\hline LCl-6 & $\mathrm{R}$ & 704 & 639 & 3 & $30,243,945$ & $30,243,307$ & 61 & -1 & 1 & intron \\
\hline LCl-7 & L & 199 & 126 & 6 & $20,057,801$ & $20,057,926$ & 73 & 238 & 1 & intergene \\
\hline \multirow[t]{2}{*}{ LCl-8 } & L & 210 & 197 & 3 & $30,990,975$ & $30,991,171$ & 14 & 211 & 2 & n.d \\
\hline & $\mathrm{R}$ & 347 & 275 & 9 & $17,404,938$ & $17,405,212$ & 72 & 348 & & \\
\hline LCl-10 & $\mathrm{R}$ & 214 & 64 & 2 & 46,488 & 46,425 & & & 1 & intergene \\
\hline \multirow[t]{2}{*}{ LCl-11 } & $L$ & 318 & 318 & 12 & 798,649 & 798,332 & -1 & 319 & 1 & intergene \\
\hline & $\mathrm{R}$ & 590 & 521 & 12 & 798,672 & 799,192 & 72 & 591 & & \\
\hline \multirow[t]{2}{*}{$\mathrm{LCl}-13$} & L & 395 & 395 & 9 & $16,474,041$ & $16,474,435$ & -1 & 396 & 2 & n.d \\
\hline & $\mathrm{R}$ & 211 & 184 & 5 & $24,829,622$ & $24,829,805$ & 25 & 212 & & \\
\hline \multirow[t]{2}{*}{ LCl-17 } & L & 684 & 681 & 3 & $31,691,652$ & $31,690,972$ & -1 & -1 & 1 & intron \\
\hline & $\mathrm{R}$ & 546 & 437 & 3 & $31,691,676$ & $31,692,112$ & 70 & 547 & & \\
\hline LCl-18 & $\mathrm{R}$ & 217 & 146 & 1 & $32,792,438$ & $32,792,293$ & 72 & 218 & 1 & intron \\
\hline
\end{tabular}

* $L$ and $R$, left and right border sequences, respectively.

"Rice Annotation Project Database (RAP-DB) was used to retrieve rice annotation information.

N.d., not determined. 

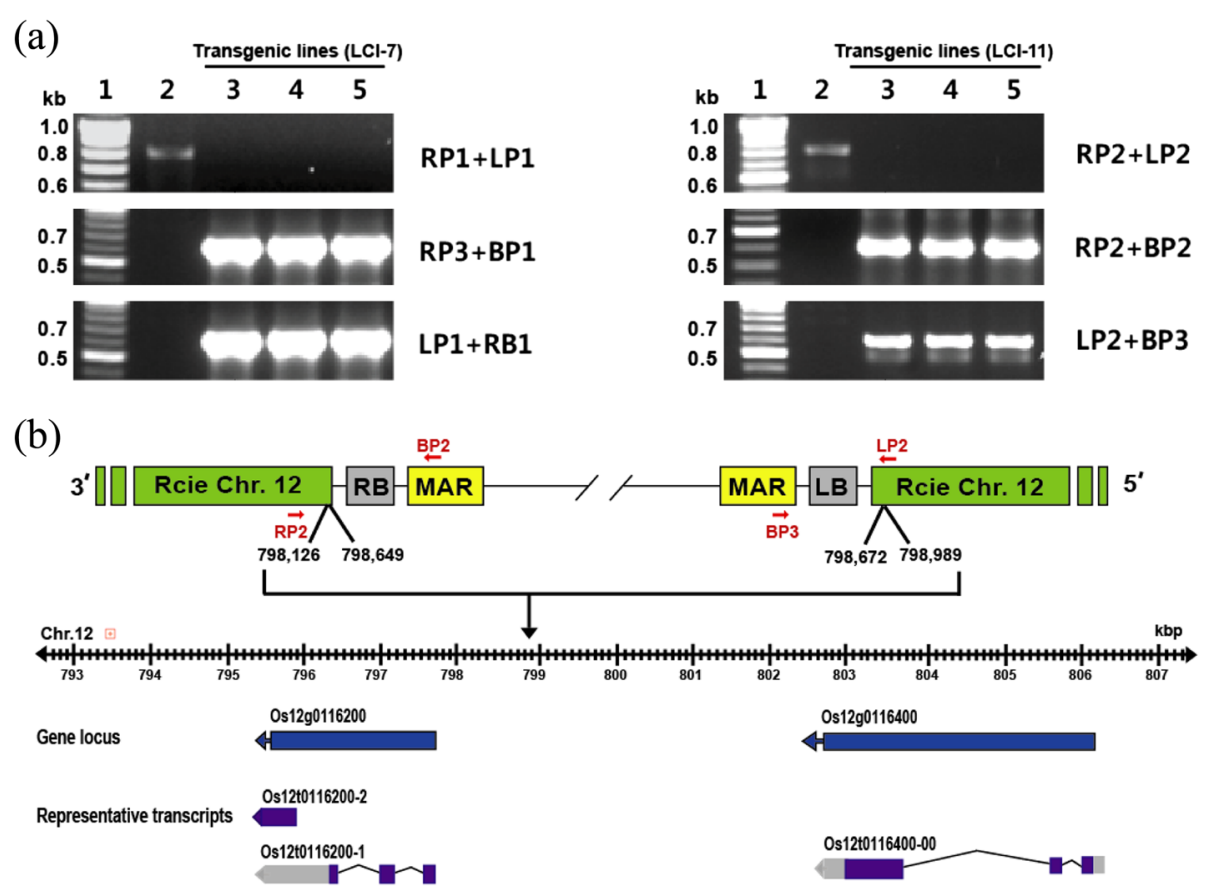

Figure 3 Homozygosity of transgenic rice lines (LCl-7 and LCl-11) was analyzed by PCR using RP, LP, BP, and RB sequences. (a) Three primer combinations were used in LCl-7 (left) and LCl-11 (right): the first comprised gene-specific right and left primers (RP1 + LP1 and RP2 + LP2); the second comprised a gene-specific right primer and T-DNA right border primer (RP3 + BP1 and RP2 + BP2); the third comprised a gene-specific left primer and a T-DNA left border primer (LP1 + RB1 and LP2 + BP3). Amplicon sizes are indicated on the right (in kb). (b) T-DNA insertion on chromosome 12 in the LCl-11 rice line. The chromosome regions in which T-DNA insertions were found ranged from 798,649 to 798,672 bp in length.

and/or CTB intraperitoneally (IP) and orally. For intraperitoneal immunization, $100 \mu \mathrm{g}$ of LTB and CTB proteins were injected into mice. Purified, E. coli-expressed LTB and CTB proteins were used as positive controls. Serum samples collected from mice at various time points and the levels of anti-LTB and CTB IgG were determined up to a 10,000-fold dilution. Mice immunized with recombinant $\mathrm{LTB}$ and $\mathrm{CTB}$ proteins, and transgenic rice-produced LTB and CTB developed significantly higher levels of LTB- and CTB-specific serum IgG compared to the wild-type (Figure 6a). No serum LTB- or CTB-specific IgG was detected in mice immunized with a PBS control. Similarly, $100 \mathrm{mg}$ of powdered samples in PBS from transgenic plants were fed orally to mice. Systemic LTB- and CTB-specific IgG and mucosal LTBand CTB-specific IgA immune responses were induced in the sera collected from mice immunized orally with LCI-11 (Figure 6b). The level of IgG and IgA was similar in mice immunized with LTB (data not shown). Furthermore, western blotting detected LTB- or CTB-specific IgG and IgA antibodies in the serum of mice immunized with LCI-11 (Figure 6b). In addition, mice immunized with transgenic rice seeds or LTB protein developed significantly higher levels of LTB-specific IgA in feces compared with those immunized with wild-type rice seeds (Figure 6c).

\section{Discussion}

Cholera and diarrheal diseases caused by enterotoxigenic Escherichia coli (ETEC) and V. cholerae are major global health problems. Cholera is the most severe ETEC infection, causing a large number of cases each year (Notaro and Kaper 1998). Effective vaccines could confer protection against these diseases by inducing an immune response and inhibiting enterotoxin activity. Immune-response-inducing toxins such as LTB and CTB are currently used as oral vaccines against diarrheal diseases. However, the production of these vaccines is expensive and requires stringent purification steps and delivery. Previously, several groups have demonstrated the production and oral immunogenicity of CTB and LTB in diverse transgenic plants (Jani et al. 2004; Rosales-Mendoza et al. 2008; Kim et al. 2009; Kajiura et al. 2013; Karaman et al. 2012; Yuki et al. 2013). Although several plant species are used for production of edible vaccines, seed crops-such as maize, wheat, or rice - are the most suitable. Among them, the use of transgenic rice for vaccine production offers several advantages over other plants. The benefits of producing edible vaccines in rice seeds include the production of large amounts of vaccine antigen for immunization, extended storage times at room temperature, and effective delivery of the vaccine to mucosal tissues. 


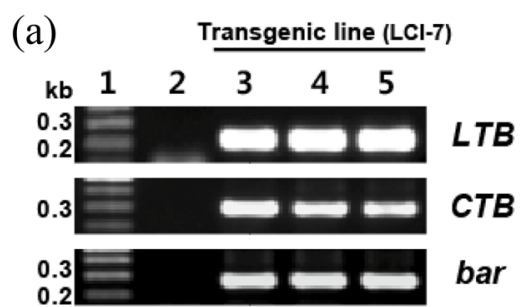

(b)
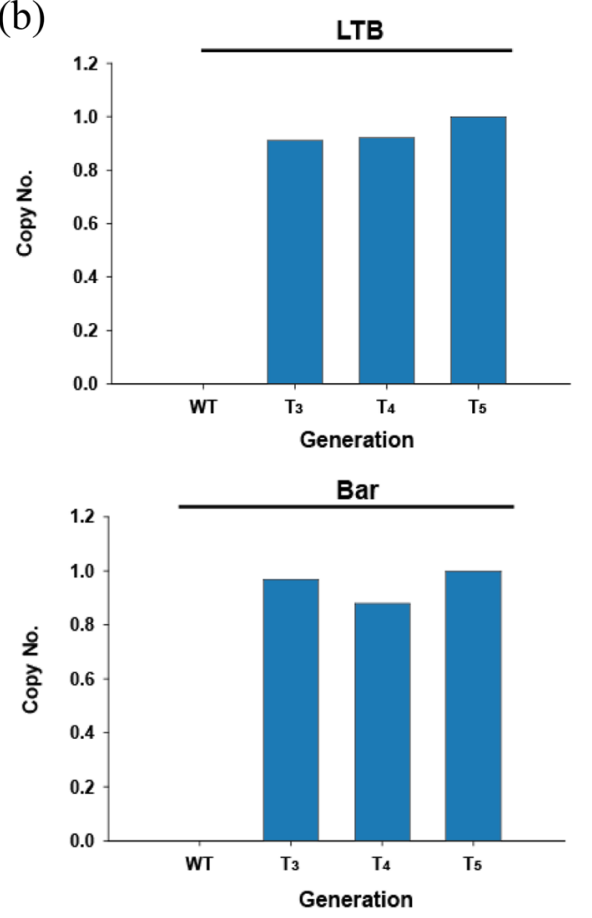
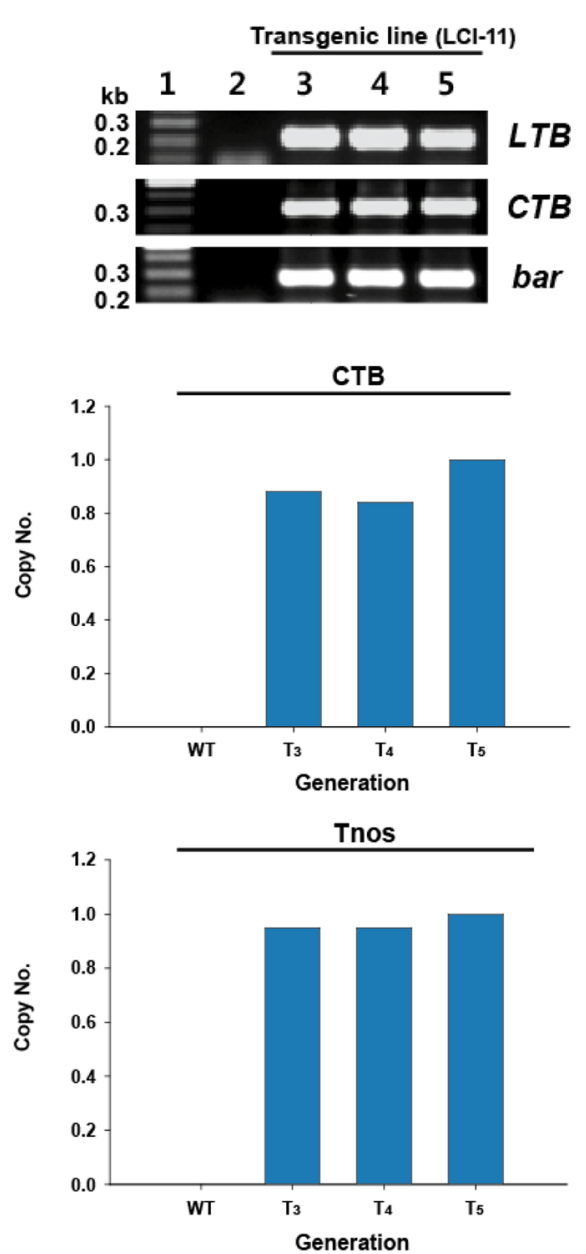

Figure 4 Molecular analyses of transgenic plants by PCR and real-time PCR in the LCl-7 and LCl-11 lines ( $\mathrm{T}_{3}$, $\mathrm{T}_{4}$ and $\mathrm{T}_{5}$ generations). (a) Genomic DNA isolated from $T_{3}$ to $T_{5}$ transgenic plants of LCl-7 (left) and LCl-11 (right) lines was used and the bar, LTB, and CTB genes were amplified by PCR. Lane 1: 1 kb marker: Lane 2: wild-type rice: Lane 3, 4 and 5: $T_{3-5}$ transgenic rice. (b) The LTB, CTB, and bar gene, and Tnos, copy numbers were analyzed in the $T_{3}, T_{4}$ and $T_{5}$ generations of the $L C l-11$ rice line by real-time PCR.

Results from the present study indicate the potential for vaccine production in rice, an important cereal crop. In the current study, we focused on expressing CTB and LTB proteins in rice (Oryza sativa. L). A total of $25 \mathrm{pu}-$ tative transgenic rice plants showed the presence of $C T B, L T B$ and bar genes, and plants were designated $\mathrm{T}_{0}$. The $\mathrm{T}_{0}$ plants harbored single and multiple copies of the LTB gene, as determined by Southern blotting. Expression levels of LTB and CTB proteins in grains were determined based on ganglioside-dependent ELISA. Levels of both proteins increased when compared to the BSA standard (Figure 5a). LTB and CTB from transgenic rice seeds accounted for up to $3.4 \mathrm{ng}$ and $21.3{\mathrm{ng} \mathrm{gg}^{-1}}$ per the total soluble protein, respectively. Enhanced CTB and protein levels were reported previously in cereal crops, at up to $0.05 \mu \mathrm{g}$ in maize (Karaman et al. 2012) and $30 \mu \mathrm{g}$ and $2.35 \mathrm{mg}$ in rice (Dong et al. 1996; Kajiura et al. 2013). Similarly, LTB levels were reported to be
3.7\% (Chikwamba et al. 2002) and 1.8\% (Streatfield et al. 2002) in maize. Western blot analyses using an antiCTB polyclonal antibody showed a molecular mass of $55 \mathrm{kDa}$. Previous studies reported a similar size, which was attributed to the pentameric structure (Nochi et al. 2007; Karaman et al. 2012). The CTBs expressed in rice were in their native pentameric form and were functionally active in terms of inducing antigen-specific immune responses.

Furthermore, intraperitoneal and oral immunization of mice with transgenic rice expressing LTB and CTB induced both systemic (IgG) and mucosal (IgA) immune responses (Figure 6a, b). Administration of 100- $\mu$ g rice-expressed LTB and CTB administered IP was sufficient to induce LTBand CTB-specific IgG production (Figure 6a). The levels of LTB- and CTB-specific IgG following IP administration in mice were similar. Furthermore, oral immunization of mice with LTB induced both systemic and mucosal IgA 


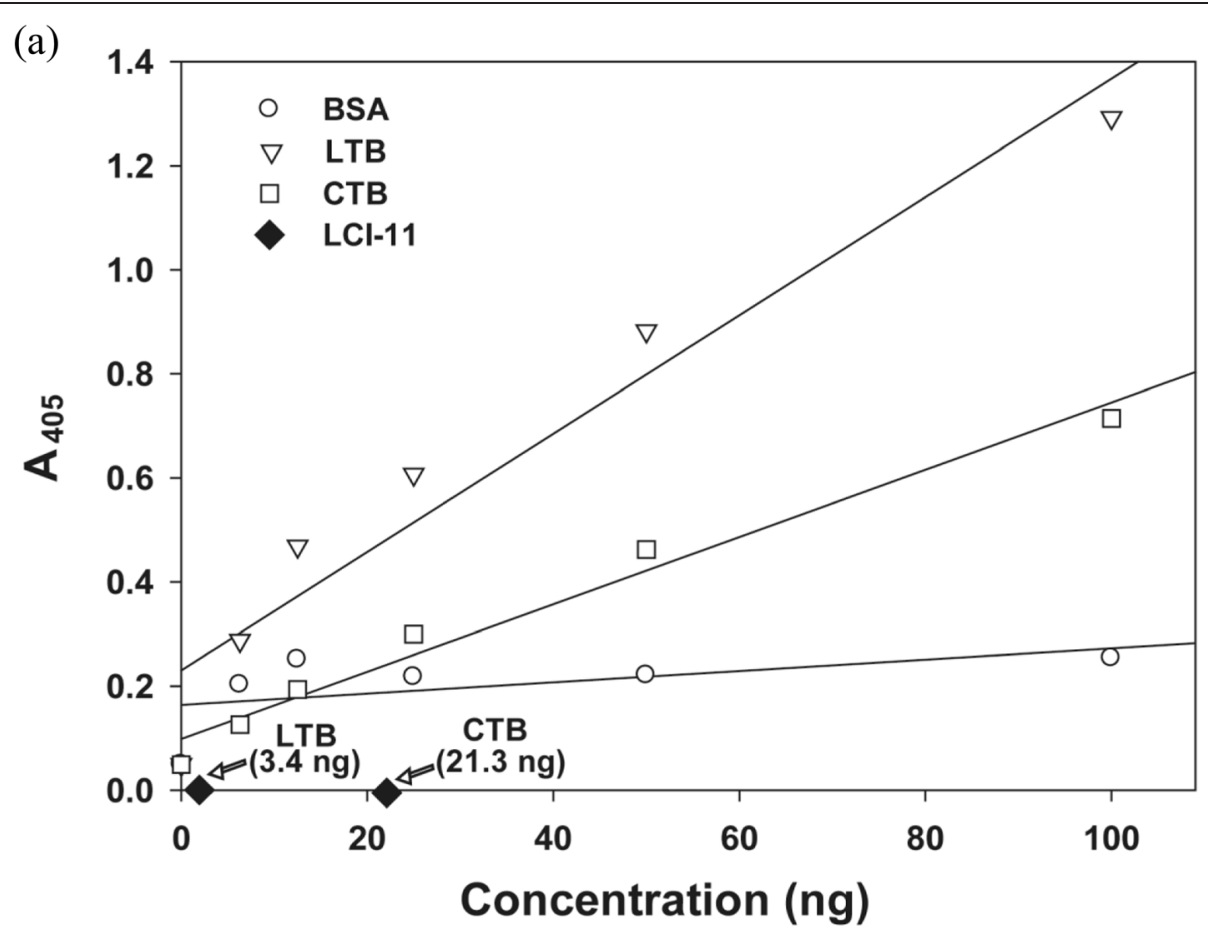

(b)
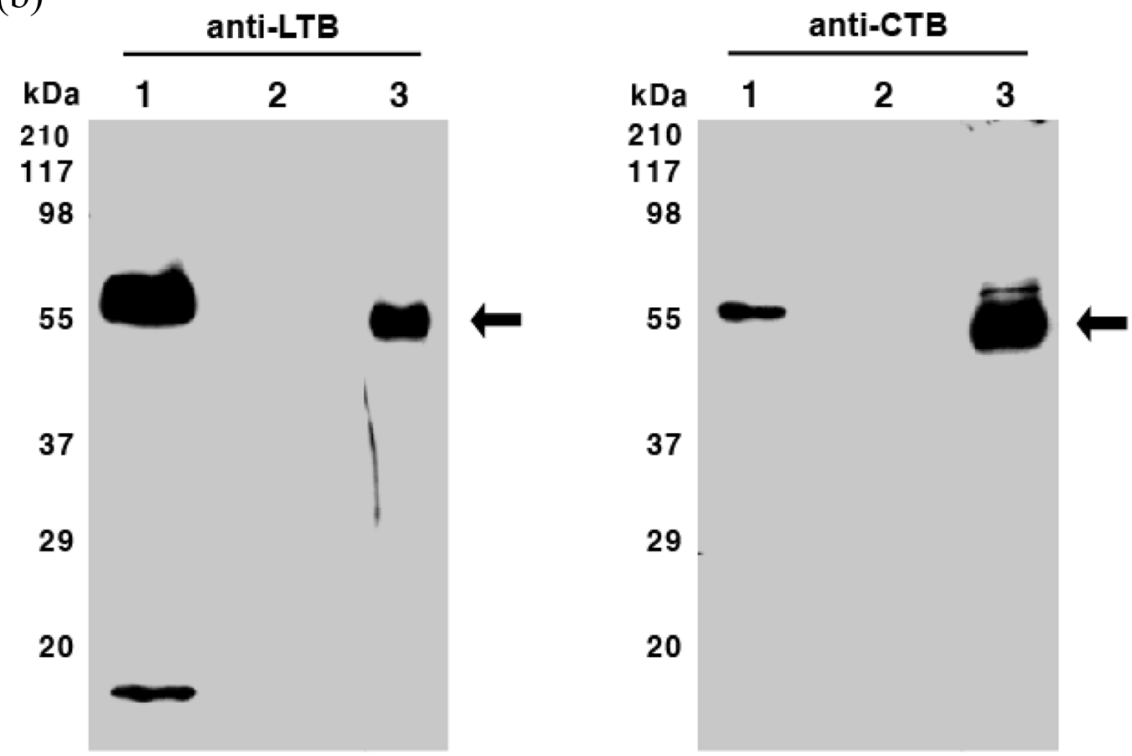

Figure 5 Recombinant LTB and CTB protein expression by transgenic rice seeds. (a) $G_{M 1}$-ganglioside receptor binding assay of LTB and CTB protein expression in transgenic rice. The relative amount of $\mathrm{LTB}$ and $\mathrm{CTB}$ proteins present in $\mathrm{LCl}-11$ was estimated by standard curves of recombinant LTB and CTB proteins, respectively. Arrows indicate relative amount of LTB and CTB proteins in LCI-11. BSA, bovine serum albumin. (b) Western blot analysis of LTB and CTB expression by transgenic rice seeds using LTB- (left) and CTB- (right) specific antibodies, respectively. Lane 1: positive control. Lane 2: wild-type rice. Lane 3: transgenic rice. Arrows indicate LTB and CTB proteins.

production. These findings are in agreement with previous reports of rice-expressed CTBs (Nochi et al. 2007; Yuki and Kiyono 2009; Tokuhara et al. 2010; Yuki et al. 2013). Systemic LTB- and CTB-specific IgG levels were similar in orally immunized mice (Figure 6b). However, production of low levels of CTB-specific IgG in orally immunized mice with maize-derived CTB mixed with maize-derived LTB suggested that LTB-specific IgG cross-reacted with CTB IgG, while CTB-specific IgG did not (Karaman et al. 2012). The level of LTB-specific mucosal IgA was increased compared to that of CTB-specific IgA. Moreover, feeding of maize-derived LTB resulted in significantly higher serum levels of LTB-specific IgA, suggesting that the maizesynthesized LTB was stable in maize tissues and was likely 
(a)

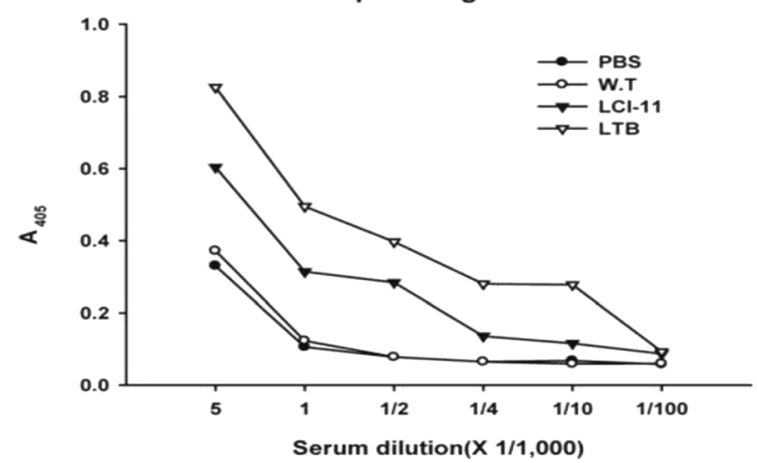

(b)

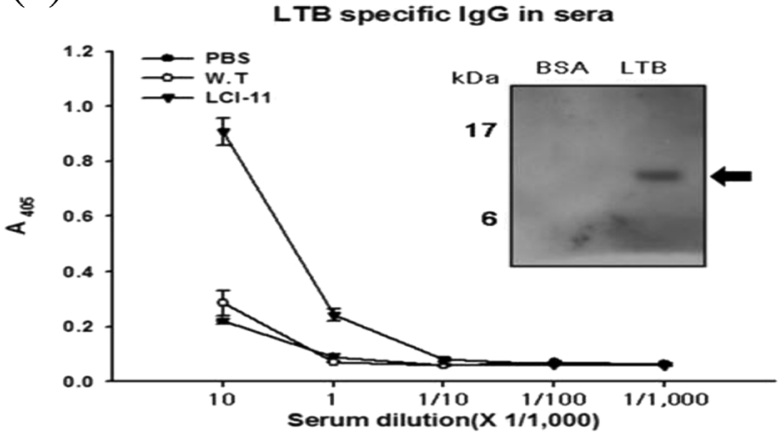

LTB specific IgA in sera

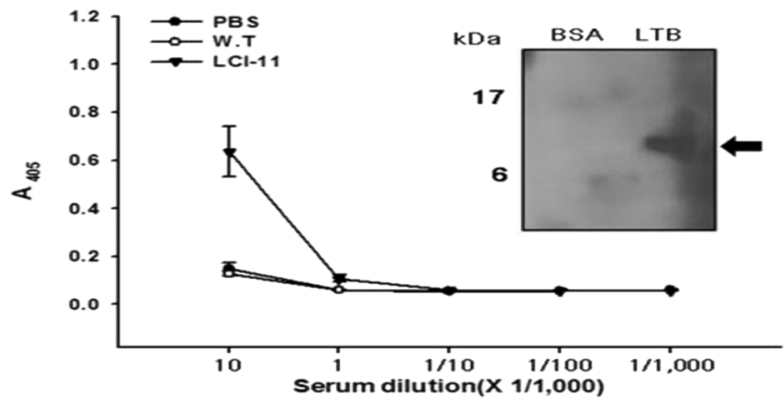

(c)

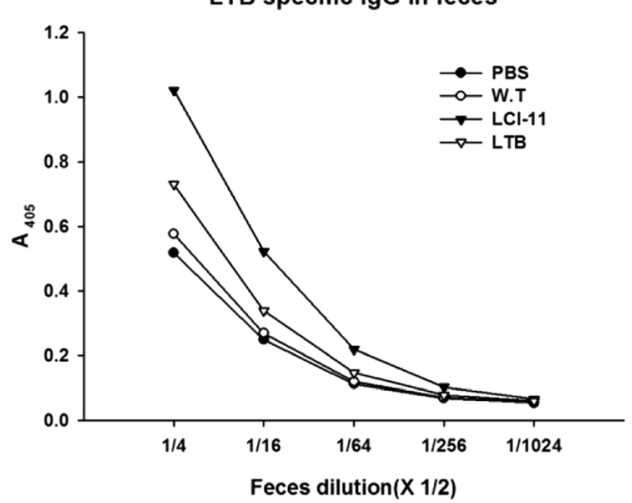

LTB specific IgG in feces
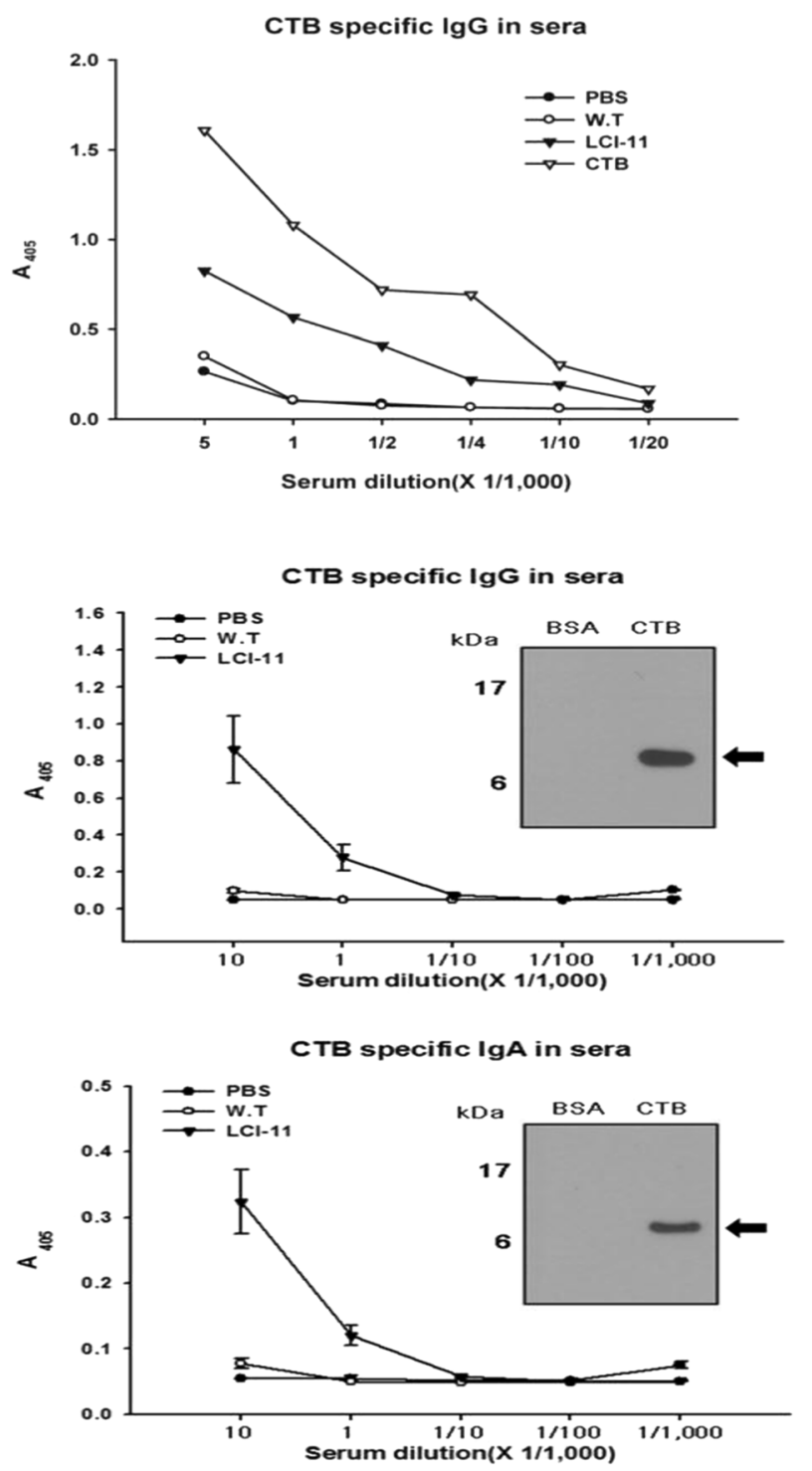

Figure 6 (See legend on next page.) 
(See figure on previous page.)

Figure 6 Levels of LTB- and CTB-specific IgG and IgA in mouse serum and feces. (a) CTB- and LTB-specific systemic IgG and mucosal IgA in mouse serum following intraperitoneal injection of wild-type (WT) and LCl-11 seeds and Ed coli-expressed LTB and CTB proteins. (b) LTB- and CTB-specific systemic IgG and mucosal IgA in mouse serum fed orally with wild-type and transgenic rice seeds. PBS was used as the negative control. Western blot (inset) detection of LTB- and CTB-specific lgG and IgA in mice immunized orally with LCl-11. First lane, BSA; second lane, LTB or CTB proteins, respectively. (c) LTB-specific mucosal IgA levels in mouse feces fed orally with recombinant LTB protein, wild-type and transgenic rice seeds. PBS was used as the negative control.

released slowly during digestion by LTB-immunized mice (Chikwamba et al. 2002).

Overall, these results suggest that the induction of systemic and mucosal immunity is enhanced by the combined administration of LTB and CTB, which strengthens the immune response in mice. CTB and LTBs expressed in corn (Tacket et al. 2004), maize (Karaman et al. 2012) and rice seeds (Nochi et al. 2007; Yuki et al. 2013) alone or in combination have been used to evaluate the use of corn as an edible agent against cholera and traveler's diarrhea. The synergistic action of CTB and LTB in seeds could be enhanced by further breeding to advanced generations. In this study, we transformed rice capable of synthesizing detectable amounts of fused CTB and LTB subunit protein. This rice-based vaccine can be used as a combined vaccination system effective against both CTbased cholera and LT-based traveler's diarrhea. The immunogenic and adjuvant abilities of the LTB and CTB proteins using mucosal immunization should be further evaluated in animal studies.

\section{Conclusions}

In this study, we transformed rice capable of synthesizing detectable amounts of CTB and LTB subunit proteins. This can be used as a combined vaccine effective against both CT-mediated cholera and LT-mediated traveler's diarrhea. The immunogenic and adjuvant abilities of the LTB and CTB proteins using mucosal immunization should be further evaluated in animal studies.

\section{Materials and methods}

\section{Reagents and apparatus}

Murashige and Skoog (MS) medium, spectinomycin, and sucrose were purchased from MB cell (CA, U.S.A). Tetracycline, cefotaxime and phosphinothricin were purchased from Duchefa (Haarlem, Netherlands). The pMJ103 vector was constructed by GreenGene BioTech (Yongin, Korea) and the plasmids (MYO51, MYO53) containing $L T B$ and/or $C T B$ were kindly donated from Dr. M.S. Yang (Chonbuk National University). T4 DNA ligase and restriction endonucleases were obtained from Roche (Basel, Switzerland). Gateway BP and LR recombinase systems were purchased from Invitrogen (Breda, Netherlands). A mini trans-blot cell and Mini-Protean III cell were purchased from Bio-Rad (Hercules, CA, USA). Reagents for SDS-polyacrylamide electrophoresis, such as acrylamide, bis-acrylamide, ammonium persulfate, TEMED, prestained molecular weight markers and Coomassie Brilliant Blue R-250 solution were obtained from Bio-Rad (Hercules, CA, USA). Anti-LTB polyclonal antibody was obtained from Abcam (Cambridge, MA, USA). $\mathrm{G}_{\mathrm{M} 1}$-ganglioside and anti-rabbit IgG-conjugated alkaline phosphatase were purchased from Santa-Cruz Biotechnology (CA, USA). Thiamine- $\mathrm{HCl}$, myo-inositol, anti-CTB polyclonal antibody, and other reagents such as salts and buffer components were of analytical grade and purchased from Sigma (St. Louis, MO, USA).

\section{Vector construction}

Two PCR fragments encoding the codon-optimized $L T B$ gene (GenBank accession number: DI119695, 396 bp) and codon-optimized CTB gene (GenBank accession number: DI120788, $396 \mathrm{bp}$ ) were cloned into the pSB11 vector. Subsequently, using the Gateway BP and LR recombinase reactions, LTB (396 bp) and CTB (396 bp) fragments were cloned into the pMJ103 destination vector, including a globulin promoter $(G l b)$, two recombination sites (attB1 and attB2), and a potato protease inhibitor II terminator (PinII). These constructed overexpression binary vectors were named pMJ103-LTBCTB. To confirm the insertion of the $L T B$ and/or CTB genes in pMJ103-LTB-CTB, the overexpression binary vector was digested by Not I (30 units/ $\mu$ l, Takara) for $1 \mathrm{~h}$ at $37^{\circ} \mathrm{C}$. The restriction-digested products were analyzed by $1 \%$ agarose gel electrophoresis. Correct transfer of the $L T B$ and CTB fragments and the presence of Glb and $P$ in II border regions in each vector were confirmed by DNA sequencing.

\section{Rice transformation}

The Agrobacterium-mediated transformation of rice (Oryza sativa cv. Ilmi) was performed as described previously (Dong et al. 1996) with minor modifications. Briefly, embryogenic callus formation was induced by placing the mature embryos (scutellum side up) in $2 \mathrm{~N} 6$ [Chu N6 medium (MB cell, CA, U.S.A) supplemented with $2 \mathrm{mg} \mathrm{L}^{-1}$ 2,4-D, $30 \mathrm{~g} \mathrm{~L}^{-1}$ sucrose, $0.5 \mathrm{~g} \mathrm{~L}^{-1}$ proline, $0.5 \mathrm{~g} \mathrm{~L}^{-1}$ glutamine, $0.3 \mathrm{~g} \mathrm{~L}^{-1}$ casamino acids, and solidified with $2.5 \mathrm{~g} \mathrm{~L}^{-1}$ Phytagel (Sigma, MO, U.S.A)] at $\mathrm{pH}$ 5.8. After 4 weeks of incubation in the dark at $27^{\circ} \mathrm{C}$, the scutellar-derived callus was used for rice callus transformation. Calli were inoculated with an overnight 
culture of LBA4404 harboring pMJ103-LTB-CTB and were grown to an $\mathrm{OD}_{600}$ of 1.5-2.0 in AAM medium supplemented with $100 \mu \mathrm{M}$ acetosyringone (Hiei et al. 1994). Co-cultivation was performed in the dark at $24^{\circ} \mathrm{C}$ for 7 days in half-strength Chu N6 medium supplemented with $10 \mathrm{~g} \mathrm{~L}^{-1}$ glucose, $100 \mu \mathrm{M}$ acetosyringone, $2 \mathrm{mg} \mathrm{L}^{-1} 2$, 4-dichlorophenoxyacetic acid, and $3 \mathrm{~g} \mathrm{~L}^{-1}$ Phytagel at $\mathrm{pH}$ 5.2. After 5 weeks of incubation in the dark at $27^{\circ} \mathrm{C}$, somatic embryogenic calli were transferred to regeneration medium [MS (MBcell) supplemented with $5 \mathrm{mg} \mathrm{L}^{-1}$ kinetin, $1 \mathrm{mg} \mathrm{L} \mathrm{L}^{-1} \alpha$-naphthalene acetic acid, $30 \mathrm{~g} \mathrm{~L}^{-1}$ sorbitol, $20 \mathrm{~g} \mathrm{~L}^{-1}$ maltose, $3 \mathrm{mg} \mathrm{L}^{-1} \mathrm{~L}$ phosphinothricin, $250 \mathrm{mg} \mathrm{L}^{-1}$ cefotaxime, and $4 \mathrm{~g} \mathrm{~L}^{-1}$ Phytagel at pH 5.8. The developing plantlets were subsequently transferred to magenta boxes and stored in pots covered with polyethylene bags for 7-14 days, after which they were transferred to a greenhouse. PCR was performed to check the presence of each fragment ( $L T B$ and $C T B$ ) in the transformed Agrobacterium LBA4404 compared with the control.

\section{DNA extraction}

Genomic DNA was extracted from fresh leaf tissues of putative transgenic plants using the DNA extraction kit (Bioneer, Korea) and purified after the RNase treatment, phenol-chloroform extraction, and ethanol precipitation. Purified DNA was analyzed using $0.8 \%$ agarose gel electrophoresis and quantified using the Nano-Drop 2000 (Thermo Scientific, U.S.A). Only high-quality genomic DNA was used for PCR and Southern blot analysis.

\section{PCR analysis}

To confirm the presence of the LTB and CTB genes in the plantlets, PCR analysis of the putative transformants was performed using the forward (LTB-F) and reverse primers (LTB-R) for the LTB gene, and forward (CTB-F) and reverse primers (CTB-R) for the CTB gene. For the bar gene, forward (Bar-F) and reverse primers (Bar-R) were also used (Table 2). PCR was performed in an HP thermocycler under the following conditions: $95^{\circ} \mathrm{C}$ for $30 \mathrm{~s}, 54^{\circ} \mathrm{C}$ for $30 \mathrm{~s}$, and $72^{\circ} \mathrm{C}$ for $2 \mathrm{~min}$ for 35 cycles. PCR products were separated on a $1 \%$ agarose gel and photographed.

\section{Trait LL lateral flow test}

Three rice seeds (wild-type and transgenic seeds) were ground and homogenized in $500 \mu \mathrm{l}$ of $\mathrm{ddH}_{2} \mathrm{O}$. After 5 min of decantation, the clear supernatant was immediately used in the lateral-flow assay.

\section{Southern blot}

Genomic DNA from the transgenic plants was digested with the XhoI restriction enzyme (2,000 U, Takara). The resulting fragments were fractionated on a $1 \%$ agarose
Table 2 Primer sets used to confirm the presence of genes

\begin{tabular}{|c|c|}
\hline Name & Sequences $\left(5^{\prime}-3^{\prime}\right)$ \\
\hline Bar-F & ACTACATCGAGACAAGCACGGT \\
\hline Bar-R & GCTCTACACCCACCTGCTGAAGT \\
\hline CTB-F & ATGGTGAAGCTCAAGTTCGG \\
\hline CTB-R & CTACTITCCAAGTTGAGGTTC \\
\hline LTB-F & ATGGTGAAGGTGAAGTGCTAC \\
\hline LTB-R & ATCACATACCTCACCGAGAC \\
\hline bar-F & GCATGACGTATTTATGAGATGGGTII \\
\hline bar-R & TGCGCGCTATATTTTGTTTCTATCG \\
\hline $\mathrm{CT}-\mathrm{F}$ & GTGTTCTTCACAGTTCTCCTCTCC \\
\hline$C T-R$ & TCGTTGAGAGTATGAATTTGTGTGTTG \\
\hline LT-F & CCTCACCGAGACCAAGATTGATAAG \\
\hline LT-R & GTACCTCATAGCTCATCTITCTCAGAG \\
\hline Tnos-F & TCCCGTCCGCTGGTG \\
\hline Tnos-R & TGCGCGCTATATTTTGTTTCTATCG \\
\hline Actin-F & CAGCCCCTCGTCTGCGATAA \\
\hline Actin-R & GCCGACGTAGGCGTCCTTCT \\
\hline
\end{tabular}

gel, denatured, and transferred from the gel onto a Hybond $\mathrm{H}^{+}$nylon membrane (Amersham Pharmacia Biotech) using the capillary transfer method (Sambrook and Russell 2006). The probe for the LTB gene was prepared by PCR from pMJ103-LTB-CTB. A total of $25 \mathrm{ng}$ of $L T B$ probe DNA were denatured at $100^{\circ} \mathrm{C}$ for $5 \mathrm{~min}$. After cooling on ice for $5 \mathrm{~min}$, denatured DNA was added to the mixture. After mixing with $5 \mu \mathrm{l}$ of $\left[\alpha{ }^{32} \mathrm{P}\right]$ $\mathrm{dCTP}$, probe DNA was incubated at $37^{\circ} \mathrm{C}$ for $10 \mathrm{~min}$ and labeled using Rediprime ${ }^{\mathrm{Tx}}$ II Random Prime Labeling system (GE Healthcare). The reaction was terminated by adding $5 \mu \mathrm{l}$ of $0.2 \mathrm{M} \mathrm{Na-EDTA}$ and the radiolabeled probe was purified using the PROBER ${ }^{\mathrm{m}}$ Probe DNA purifying system (Intronbio, Korea). Purified labeled DNA was denatured by heating at $100^{\circ} \mathrm{C}$ for $5 \mathrm{~min}$, stored on ice, and mixed with hybridization solution. Membranes were soaked in the pre-hybridization solution (6x SSC, $5 \times$ Denhardt's reagent, $0.5 \%$ SDS and $100 \mu \mathrm{g} / \mathrm{ml}$ denatured fragmented salmon sperm DNA) at $65^{\circ} \mathrm{C}$ with gentle shaking. After $2 \mathrm{~h}$, hybridization was performed in hybridization solution $(6 \times$ SSC, $0.5 \%$ SDS and $100 \mu \mathrm{g} / \mathrm{ml}$ denatured fragmented salmon sperm DNA) containing the probe overnight at $65^{\circ} \mathrm{C}$ in a shaking incubator. After washing the membranes with the appropriate washing solutions and temperatures $(2 x$ SSC in $0.5 \%$ SDS at $25^{\circ} \mathrm{C}, 2 \times \mathrm{SSC}$ in $0.1 \%$ SDS at $25^{\circ} \mathrm{C}$, $0.1 \times \mathrm{SSC}$ in $0.5 \% \mathrm{SDS}$ at $37^{\circ} \mathrm{C}, 0.1 \times \mathrm{SSC}$ in $0.5 \% \mathrm{SDS}$ at $65^{\circ} \mathrm{C}$, and $0.1 \times \mathrm{SSC}$ ), they were dried, covered in Saran wrap, and exposed to X-ray film (Kodak MS). 


\section{RT-PCR analysis}

Total RNAs were isolated from rice seeds $(150 \mathrm{mg})$ using TRIzol reagent according to the manufacturer's instructions (Invitrogen, Breda, Netherlands). The RNA integrity was assessed under UV light by visualization of the 28S- and 18S-rRNA bands on a $1.5 \%$ agarose gel containing ethidium bromide. For reverse transcription (RT)-PCR analysis, total RNA samples were treated with DNase before reverse transcription, according to the manufacturer's instructions (Takara). RT-PCR amplification was performed in a reaction mixture containing $1 \mu \mathrm{g}$ total RNA, $1 \times$ One Step RNA PCR buffer, $0.8 \mathrm{U}$ RNase inhibitor, $0.4 \mu \mathrm{M}$ of each primer, $0.1 \mathrm{U}$ AMV RTase XL, 0.1 U AMV-optimized Taq DNA polymerase, $5 \mathrm{mM}$ dNTP, and $5 \mathrm{mM} \mathrm{MgCl}$ (Takara). The reaction mixture was heated at $50^{\circ} \mathrm{C}$ for $30 \mathrm{~min}$ and $94^{\circ} \mathrm{C}$ for 2 min for reverse transcription and inactivation of reverse transcriptase, respectively. The reaction mixture was amplified by 35 cycles, each consisting of $30 \mathrm{~s}$ at $94^{\circ}$ $\mathrm{C}, 30 \mathrm{~s}$ at $60^{\circ} \mathrm{C}$, and $30 \mathrm{~s}$ at $72^{\circ} \mathrm{C}$. After termination of the last cycle, the samples were incubated at $72^{\circ} \mathrm{C}$ for $10 \mathrm{~min}$ and chilled at $4^{\circ} \mathrm{C}$. Specific primers were used for the amplification of LTB (LT-F and LT-R) and CTB (CT-F and CT-R), resulting in an amplified products of 107 and 111 bp, respectively. Actin-1 (GenBank accession number: KC140126) served as an internal control. Specific primers were used for the amplification of actin-1 (actin-F and actin-R), resulting in an amplified product of $150 \mathrm{bp}$. The amplified PCR products were electrophoresed on a $1 \%$ agarose gel containing ethidium bromide and photographed.

\section{Flanking DNA sequencing and PCR of homozygous transgenic plants}

Genomic DNA (500 ng) from the third-generation $\left(\mathrm{T}_{3}\right)$ transgenic plants was digested with the restriction enzyme XhoI (2 U, Takara) and ligated with $5 \mathrm{U}$ of T4 DNA ligase (Takara) in a $20-\mu \mathrm{l}$ reaction volume. The reaction mixture containing T4 DNA ligase buffer and 50 $\mathrm{pM}$ of the adaptors was incubated at $37^{\circ} \mathrm{C}$ for $1 \mathrm{~h}$. The first PCR was conducted using $0.5 \mathrm{pM}$ specific primers (Ada1 and LB1; and Ada1 and RB1an), as shown in Table 3 and $1 \mu \mathrm{l}$ of digestion/ligation product in a $20-\mu \mathrm{l}$ reaction. PCR was performed using a PTC-200 thermal cycler (MJ research) under the following conditions: $95^{\circ}$ $\mathrm{C}$ for $5 \mathrm{~min}, 20$ cycles of $94^{\circ} \mathrm{C}$ for $30 \mathrm{~s}$ and $72^{\circ} \mathrm{C}$ for $1 \mathrm{~min}$, followed by a final elongation step at $72^{\circ} \mathrm{C}$ for $10 \mathrm{~min}$. Second PCRs were conducted with $5 \mu \mathrm{l}$ of the first PCR product using specific primers (Ada2, and LB2; and Ada2, and RB2) with an initial denaturing step at $94^{\circ} \mathrm{C}$ for $5 \mathrm{~min}, 40$ cycles of $94^{\circ} \mathrm{C}$ for $30 \mathrm{~s}, 60^{\circ} \mathrm{C}$ for $30 \mathrm{~s}$, and $72^{\circ} \mathrm{C}$ for $1 \mathrm{~min}$, followed by a final elongation at $72^{\circ}$ C for $10 \mathrm{~min}$. Amplified products were loaded on a 1\% agarose gel and the PCR products were purified using
Table 3 Primers used for sequencing of flanking regions and selection of homozygous plants

\begin{tabular}{ll}
\hline Name & Sequences (5'-3') \\
\hline Ada1 & GCGTAATACGACTCACTATAGCAATTAACC \\
Ada2 & GACTCACTATAGCAATTAAC \\
LB1an & AAGCCGTCAGGAGCTCGAATTCAGTACA \\
LB2 & CATTAAAAACGTCCGCAATG \\
RB1an & AAGCTTGCTGAGTGGCTCCTTCAACG \\
RB2 & GCTTGCTGAGTGGCTCCTTC \\
BP1 & TATCAAAGAAGGCGGCAGGAGCCACCG \\
BP2 & TGCCGTTCCTGAGCACGCA \\
BP3 & TATCAAAGAAGGCGGCAGGAGCC \\
LP1 & TCGAAGCAGCCGATGAGCTTGA \\
LP2 & TTGGCGTCGGCTCCTGGAT \\
RB1 & AGATTGTCGTTCCCGCCTTC \\
RP1 & TGGTATCATGGAAACGCGGGG \\
RP2 & TCTTAGACCCGTTGGGCCGTG \\
RP3 & GAGAGAGATGATGTGGCATCTGACAC \\
\hline
\end{tabular}

the HiYield ${ }^{\text {ix }}$ Gel/PCR DNA Extraction Kit (RBC) and sequenced by ABI3730XL using LB2 or RB2 primers.

The third_generation homozygous transgenic lines derived from LCI-7 and LCI-11 plants were analyzed by PCR of genomic DNA. The PCR was conducted with 0.5 pM of each primer to amplify the wild-type allele (RP1 and LP1; and RP2 and LP2), the T-DNA insertion allele (RP3 and BP1; and RP2 and BP2), and the second T-DNA insertion allele (LP1 and RB1; and LP2 and BP3). PCR was performed using a PTC-200 thermal cycler (MJ research) with the following reaction conditions: $95^{\circ} \mathrm{C}$ for $5 \mathrm{~min}$, 30 cycles of $94^{\circ} \mathrm{C}$ for $30 \mathrm{~s}, 60^{\circ} \mathrm{C}$ for $1 \mathrm{~min}$ and $72^{\circ} \mathrm{C}$ for $1 \mathrm{~min}$, followed by a final elongation at $72^{\circ} \mathrm{C}$ for $10 \mathrm{~min}$.

\section{Quantitative real-time PCR}

qRT-PCR was performed in a 96-well format in the ABI 7500 Real-Time System (Applied Biosystems) with specific primers (designed using copy caller software) used to amplify a 100-bp fragment of LTB (LT-F and LT-R), CTB (CT-F and CT-R), Bar (bar-F and bar-R), and Tnos (Tnos$\mathrm{F}$ and Tnos-R), as shown in Table 2. qRT-PCR was performed under the following conditions: $95^{\circ} \mathrm{C}$ for $10 \mathrm{~min}$ followed by 40 cycles of $95^{\circ} \mathrm{C}$ for $15 \mathrm{~s}$ and $60^{\circ} \mathrm{C}$ for $60 \mathrm{~s}$. Three replicates were prepared from the same genomic DNA and the copy number of each gene. Expression levels of the CTB, LTB, Tnos and bar genes were normalized to that of $\alpha$-tubulin as the reference gene.

\section{$\mathrm{G}_{\mathrm{M} 1}$-ganglioside binding assay}

Transgenic and wild-type rice seeds ( $2 \mathrm{~g}$ ) were homogenized in $5 \mathrm{ml}$ of buffer containing $0.1 \mathrm{M} \mathrm{mM}$ Tris- $\mathrm{HCl}$ (pH 8.0), $1 \mathrm{mM}$ EDTA, $1 \mathrm{mM}$ DTT, and $1 \times$ protease 
inhibitor cocktail (Sigma). Insoluble material was removed by centrifugation. Protein concentrations were determined using the Bradford protein assay reagent kit (Bio-Rad, Hercules, CA). The $\mathrm{G}_{\mathrm{M} 1}$-ganglioside binding capability of recombinant LTB and CTB proteins expressed in transgenic rice seeds was estimated based on ELISA. Briefly, a 96-well ELISA plate was coated with monosialoganglioside- $\mathrm{G}_{\mathrm{M} 1}$ (Santa Cruz Biotechnology) (3.0 $\mu \mathrm{g} \mathrm{ml}^{-1}$ in sodium bicarbonate buffer) or BSA $\left(3.0 \mu \mathrm{g} \mathrm{ml}^{-1}\right.$ in sodium bicarbonate buffer) as a negative control, and incubated at $4^{\circ} \mathrm{C}$ overnight. Microwell strips were washed three times with approximately $200 \mu \mathrm{l}$ of wash buffer per well. Wells were then blocked with $4 \%$ non-fat milk in PBS, washed three times with PBST and incubated with recombinant LTB (6.3 to $100 \mathrm{ng}$ ), authentic CTB (6.3 to $100 \mathrm{ng}$ ), or soluble protein from transgenic or untransformed rice seeds $(4 \mu \mathrm{g})$ in PBS for $2 \mathrm{~h}$ at $37^{\circ} \mathrm{C}$. Each well was then washed with PBS three times. Antisera against LTB (1:5,000 dilution) or CTB (1:5,000 dilution) in PBS buffer were added to each well and incubated for $2 \mathrm{~h}$ at $37^{\circ} \mathrm{C}$, after which each well was washed with PBS three times. Goat anti-rabbit IgG polyclonal antiserum conjugated with AP (1:1,000 dilutions) in PBS buffer was then added to each well and incubated for $2 \mathrm{~h}$ at $37^{\circ} \mathrm{C}$. After washing, $100 \mu \mathrm{l}$ of $p$-nitrophenylacetate were added and the plate was incubated for $15 \mathrm{~min}$. The enzyme reaction was stopped by quickly pipetting $50 \mu \mathrm{l}$ of $2 \mathrm{~N} \mathrm{H}_{2} \mathrm{SO}_{4}$ into each well. The absorbance at $405 \mathrm{~nm}$ was read using a microplate reader.

\section{Western blot analysis}

Transgenic rice seeds $(2 \mathrm{~g})$ were homogenized in $5 \mathrm{ml}$ of extraction buffer containing $100 \mathrm{mM}$ Tris $-\mathrm{HCl}$ (pH 8.0), $1 \mathrm{mM}$ DTT, $1 \mathrm{mM}$ EDTA, and $0.6 \mathrm{mM}$ PMSF. Insoluble material was removed by centrifugation at $12,000 \mathrm{rpm}$ for $20 \mathrm{~min}$. Protein concentrations were determined using the Bradford Protein Assay Reagent kit (Bio-Rad) (Bradford 1976). Total soluble proteins (100 $\mu \mathrm{g}$; the LTB

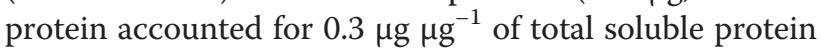
and CTB accounted for $2.1 \mu \mathrm{g} \mathrm{gg}^{-1}$ of total soluble protein) were mixed with sample buffer $(10 \%$ glycerol, $60 \mathrm{mM}$ Tris- $\mathrm{HCl} \mathrm{pH}$ 6.8, 2\% SDS, $0.01 \%$ bromophenol blue) at room temperature and were separated using $12 \%$ non-reducing SDS-polyacrylamide gel electrophoresis and then electrophoretically transferred to a PVDF membrane (iBlot ${ }^{\mathrm{Tm}}$, Invitrogen) at a constant voltage of $150 \mathrm{~V}$ at room temperature for $40 \mathrm{~min}$ in a Bio-Rad mini trans-blot cell.

The electroblotting buffer was $10 \mathrm{mM}$ CAPS-10\% methanol. The membrane was blocked to prevent nonspecific antibody binding using 5\% non-fat milk powder in Tween/Tris-buffered saline, and probed with a rabbit polyclonal antibody against LTB or CTB at 1:10,000 dilutions for $2 \mathrm{~h}$ at $37^{\circ} \mathrm{C}$. After washing three times, the blot was probed with HRP-conjugated secondary antibodies $(1: 5,000)$ for $2 \mathrm{~h}$. The ECL chemiluminescence reagent was added to the membrane as per the manufacturer's instructions. The membrane was exposed to Chemi-Doc detection reagent (Bio-Rad) for 1 min before being developed and fixed.

\section{Immunization of mice with transgenic rice seed extract}

To investigate the immunogenicity of transgenic rice seeds (LCI-11), ten females BALB/c (5 weeks old) mice were administered with transgenic rice seed samples expressing both LTB and CTB. For the intraperitoneal immunization test, wild-type and transgenic rice seeds were ground and extracted in PBS. After quantifying soluble protein, test samples $(100 \mu \mathrm{g}$ in $100 \mu \mathrm{l}$ PBS) were intraperitoneally injected into ten mice on day 1 , followed by four booster injections on days $8,15,22$, and 29. As positive controls, purified LTB ( $10 \mu \mathrm{g} /$ mouse $)$ and purified CTB (30 $\mu \mathrm{g} /$ mouse) expressed in E. coli as previous our report (Sim et al. 2009). To express CTB in E. coli, codon-optimized CTB gene was cloned at the Nterminus at Nde I site and at the C-terminus at Xho I (pET21a-CTB). The mice were divided into five groups (group 1, PBS; group 2, purified LTB; group 3, purified CTB; group 4, proteins from wild-type rice; group 5, proteins from transgenic rice) and were bled retroorbitally every week until 5 weeks post-immunization. For oral immunization, wild-type and transgenic rice seeds were ground and suspended, and rice samples (100-mg rice powder/100- $\mu \mathrm{l}$ PBS) were orally ingested by mice on day 1 followed by eight further oral administrations on days $4,7,10,13,16,19,22$, and 25 . The amount of LTB and CTB in rice seed powders $(100 \mathrm{mg})$ were approximately 90 and $110 \mu \mathrm{g}$, respectively. As positive controls, purified LTB (50 $\mu \mathrm{g} /$ mouse) expressed in E. coli was used. The mice were divided into four groups (group 1, PBS; group 2, purified LTB; group 3, wild-type rice seeds; group 4 , transgenic rice seeds), and blood was sampled on day 28. Mice sera and feces were prepared, and the presence of specific antibodies to LTB and CTB was determined by ELISA. Briefly, a 96-well ELISA plate was coated with purified LTB or CTB (200 ng/well) in ELISA coating buffer $(50 \mathrm{mM}$ sodium bicarbonatesodium carbonate, $\mathrm{pH}$ 9.6). The plate was incubated at $4{ }^{\circ} \mathrm{C}$ overnight and washed with $200 \mu \mathrm{l}$ of PBST (PBS$0.1 \%$ Tween-20) four times. The wells were then blocked with $4 \%$ non-fat milk in PBS at $37^{\circ} \mathrm{C}$ for $2 \mathrm{~h}$. After washing the wells, diluted anti-sera (1:200, 1:1,000, 1:2,000, 1:4,000, 1: 10,000, 1:20,000, 1: 1,000,000 for intraperitoneal immunization or 1:100, 1:1,000, 1:10,000, 1: 100, 000, 1: 1,000,000 for oral immunization, respectively) and diluted feces $(1: 100,1: 1,000,1: 10,000,1: 100,000,1$ : $1,000,000)$ were added to the wells and incubated at $37^{\circ} \mathrm{C}$ for $2 \mathrm{~h}$. After washing, anti-mouse IgG-HRP (1:10,000 in 
both intraperitoneal and oral immunization tests) and anti-mouse IgA-HRP (1:10,000 in only oral immunization tests) were added to each well and incubated at $25^{\circ} \mathrm{C}$ for $1 \mathrm{~h}$. After washing, $100 \mu \mathrm{l}$ of TMB $\left(3^{\prime}, 3^{\prime}, 5^{\prime}, 5^{\prime}\right.$-tetramethylbenzidine) containing $\mathrm{H}_{2} \mathrm{O}_{2}$ solution were added and the plate was incubated for $15 \mathrm{~min}$ at $37^{\circ} \mathrm{C}$. The enzyme reaction was stopped by quickly pipetting $50 \mu \mathrm{l}$ of $2 \mathrm{~N} \mathrm{H}_{2} \mathrm{SO}_{4}$ into each well. The absorbance at $450 \mathrm{~nm}$ was read using a microplate reader.

Western blot analysis was performed for the detection of LTB- and CTB-specific IgG and IgA in mice sera after oral administration of LCI-11, respectively. Purified LTB or CTB proteins (50 ng) were loaded to $12 \%$ SDSpolyacrylamide gels with BSA (50 ng) as a negative control and then transferred to PVDF membranes. After blocking, membranes were probed with anti-sera (1:500) collected from mice immunized orally with LCI- 11 at $4^{\circ} \mathrm{C}$ overnight, respectively. After washing, the blots were probed with HRP-conjugated secondary antibodies $(1: 1,000)$ for $2 \mathrm{~h}$ at $37^{\circ} \mathrm{C}$. Membranes were developed by using the ECL reagent as the manufacturer's protocol.

\section{Competing interests}

The authors declare that they have no competing interests.

\section{Authors' contributions}

HSS, JHP, ISC and BSH designed the research; HSS, HYC, HHL, KJ and GYL performed the experiments; HJL, YHH, JSS and JWL analyzed the data; HYC, $\mathrm{HA}$ and BSH wrote the manuscript. All authors read and approved the final manuscript.

\section{Acknowledgements}

This project was supported by a grant from Gyeonggido Agricultural Research \& Extension Services and the National Academy of Agricultural Science (PJ01086903), RDA, Korea. This study was supported by 2014 Postdoctoral Fellowship Program (to H.Y.C, H.A. and I.C.) of the National Academy of Agricultural Science, RDA, Korea.

\section{Author details}

${ }^{1}$ Division of Environmental Agricultural Research, Gyeonggido Agricultural Research \& Extension Services, Hwaseong 445-784, South Korea. ${ }^{2}$ Department of Agricultural Biotechnology, National Academy of Agricultural Science, Nongsaengmyeong-ro 370, Jeonju-si, Jeollabuk-do 560-550, South Korea. ${ }^{3}$ Department of Genetic Engineering and Graduate School of Biotechnology, Kyung Hee University, Yongin 446-701, South Korea.

Received: 15 May 2014 Accepted: 22 January 2015

Published online: 28 March 2015

\section{References}

Ahrén C, Wennerås C, Holmgren J, Svennerholm AM (1993) Intestinal antibody response after oral immunization with a prototype cholera B subunitcolonization factor antigen enterotoxigenic Escherichia coli vaccine. Vaccine 11(9):929-935

Arakawa T, Chong DKX, Merritt JL, Langridge WHR (1997) Expression of cholera toxin B subunit oligomers in transgenic potato plants. Transgenic Res 6 (6):403-413

Archer DB (1994) Enzyme production by recombinant Aspergillus. In: Murooka Y, Imanaka T (eds) Recombinant Microbes for Industrial and Agricultural Applications. Marcel Dekker Inc, New York

Bradford MM (1976) A rapid and sensitive method for the quantitation of microgram quantities of protein utilizing the principle of protein-dye binding. Anal Biochem 72(1-2):248-254

Chen R (2012) Bacterial expression systems for recombinant protein production: E. coli and beyond. Biotechnol Adv 30(5):1102-1107
Chikwamba R, Cunnick J, Hathaway D, McMurray J, Mason H, Wang K (2002) A functional antigen in a practical crop: LT-B producing maize protects mice against Escherichia coli heat labile enterotoxin (LT) and cholera toxin (CT). Transgenic Res 11(5):479-493

Clemens JD, Van Loon F, Sack DA, Rao MR, Ahmed F, Harris JR, Khan MR, Yunus M, Huda S (1991) Field trial of oral cholera vaccines in Bangladesh: serum vibriocidal and antitoxic antibodies as markers of the risk of cholera. J Infect Dis 163(6):1235-1242

Cui L, Chen Y, Shen G, Zhao L, Tang K (2011) Expression of bioactive thymosin alpha 1 (Ta1) in marker-free transgenic lettuce (lactuca sativa). Plant Mol Biol Rep 29(2):466-472

Dong J, Teng W, Buchholz WC, Hall TC (1996) Agrobacterium-mediated transformation of javanica rice. Mol Breed 2(3):267-276

Du G-L, Song C-Z, Zhang G-L, Sun X-G, Liu D-R (2005) Transgenic Lycium barbarum L. Established as HIV capsid protein expression system. Plant Mol Biol Report 23(4):411-416

El Adab SM, Ezzine A, Khedija IB, Chouchane L, Marzouki MN (2007) Expression of human papillomavirus type 16 major capsid protein $L 1$ in transgenic Arabidopsis thaliana. Plant Mol Biol Rep 25(3-4):133-144

Guo Q-Q, Zhang Z-L, Jiang S-J, Ma J-T, Xue W-T, Wu Y-M (2012) Expression of an avian influenza virus ( $\mathrm{H} 5 \mathrm{~N} 1$ ) hemagglutinin gene in transgenic lotus corniculatus. Plant Mol Biol Rep 30(5):1117-1124

Guzman GD, Walmsley AM, Webster DE, Hamill JD (2011) Hairy roots cultures from different Solanaceous species have varying capacities to produce $E$. coli B-subunit heat-labile toxin antigen. Biotechnol Lett 33(12):2495-2502

Haq TA, Mason HS, Clements JD, Arntzen CJ (1995) Oral immunization with a recombinant bacterial antigen produced in transgenic plants. Science 268 (5211):714-716

Harashima S (1994) Heterologous protein production by yeast host-vector systems. Bioprocess Technol 19:137-158

Hiei Y, Ohta S, Komari T, Kumashiro T (1994) Efficient transformation of rice (Oryza sativa L.) mediated by Agrobacterium and sequence analysis of the boundaries of the T-DNA. Plant J 6(2):271-282

Jani D, Meena LS, Rizwan-ul-Haq QM, Singh Y, Sharma AK, Tyagi AK (2002) Expression of cholera toxin B subunit in transgenic tomato plants. Transgenic Res 11(5):447-454

Jani D, Singh NK, Bhattacharya S, Meena LS, Singh Y, Upadhyay SN, Sharma AK, Tyagi AK (2004) Studies on the immunogenic potential of plant-expressed cholera toxin B subunit. Plant Cell Rep 22(7):471-477

Kajiura H, Wasai M, Kasahara S, Takaiwa F, Fujiyama K (2013) N-glycosylation and $\mathrm{N}$-glycan moieties of CTB expressed in rice seeds. Mol Biotechnol 54(3):784-794

Kang TJ, Loc NH, Jang MO, Jang YS, Kim YS, Seo JE, Yang MS (2003) Expression of the $B$ subunit of $E$. coli heat-labile enterotoxin in the chloroplasts of plants and its characterization. Transgenic Res 12(6):683-691

Karaman S, Cunnick J, Wang K (2012) Expression of the cholera toxin B subunit (CT-B) in maize seeds and a combined mucosal treatment against cholera and traveler's diarrhea. Plant Cell Rep 31(3):527-537

Kim TG, Kim MY, Kim BG, Kang TJ, Kim YS, Jang YS, Arntzen CJ, Yang MS (2007) Synthesis and assembly of Escherichia coli heat-labile enterotoxin B subunit in transgenic lettuce (Lactuca sativa). Protein Expr Purif 51(1):22-27

Kim YS, Kim MY, Kim TG, Yang MS (2009) Expression and assembly of cholera toxin B subunit (CTB) in transgenic carrot (Daucuscarota L.). Mol Biotechnol 41(1):8-14

Kim TG, Kim BG, Kim MY, Choi JK, Jung ES, Yang MS (2010) Expression and immunogenicity of enterotoxigenic Escherichia coli heat-labile toxin B subunit in transgenic rice callus. Mol Biotechnol 44(1):14-21

Kim MY, Kim TG, Yoo HS, Yang MS (2011) Expression and assembly of ApxIIA toxin of Actinobacillus pleuropneumoniae fused with the enterotoxigenic $E$. coli heat-labile toxin B subunit in transgenic tobacco. Plant Cell Tiss Organ Cult 105(3):375-382

Ko SM, Yoo BH, Lim JM, Oh KH, Liu Jl, Kim SW, Liu JR, Choi KS, Yoon ES (2009) Production of fibrinolytic enzyme in plastid-transformed tobacco plants. Plant Mol Biol Rep 27(4):448-453

Lebens M, Johansson S, Osek J, Lindblad M, Holmgren J (1993) Large-scale production of Vibrio cholerae toxin B subunit for use in oral vaccines. Biogeosciences 11 (13):1574-1578

Lebens M, Shahabi V, Bäckström M, Houze T, Lindblad N, Holmgren J (1996) Synthesis of hybrid molecules between heat-labile enterotoxin and cholera toxin B subunits: potential for use in a broad-spectrum vaccine. Infect Immun 64(6):2144-2150 
Ma JKC, Drake PMW, Christou P (2003) The production of recombinant pharmaceutical proteins in plants. Nat Rev Genet 4:794-805

Mason HS, Haq TA, Clements JD, Arntzen CJ (1998) Edible vaccine protects mice against Escherichia coli heat-labile enterotoxin (LT): potatoes expressing a synthetic LT-B gene. Vaccine 16(13):1336-1343

Mattanovich D, Branduardi P, Dato L, Gasser B, Sauer M, Porro D (2012) Recombinant protein production in yeasts. Methods Mol Biol 824:329-358

Nochi T, Takagi H, Yuki Y, Yang L, Masumura T, Mejima M, Nakanishi U, Matsumura A, Uozumi A, Hiroi T, Morita S, Tanaka K, Takaiwa F, Kiyono H (2007) Rice-based mucosal vaccine as a global strategy for cold-chain- and needle-free vaccination. Proc Natl Acad Sci U S A 104(26):10986-10991

Notaro JP, Kaper JB (1998) Diarrheagenic Escherichia coli. Clin Microbiol Rev 11(1):142-201

Oszvald M, Kang TJ, Tomoskozi S, Jenes B, Kim TG, Cha YS, Tamas L, Yang MS (2008) Expression of cholera toxin B subunit in transgenic rice endosperm. Mol Biotechnol 40(3):261-268

Prokop A, Bajpai RK, Ho CS (1991) Recombinant DNA technology and applications. McGraw Hill, New York

Rosales-Mendoza S, Soria-Guerra RE, Olivera-Flores MTJ, López-Revilla R, ArgüelloAstorga GR, Jiménez-Bremont JF, Cruz RFG, Loyola-Rodríguez JP, Alpuche-Solís ÁG (2007) Expression of Escherichia coli heat-labile enterotoxin b subunit (LTB) in carrot (Daucus carota L.). Plant Cell Rep 26(7):969-976

Rosales-Mendoza S, Soria-Guerra RE, López-Revilla R, Moreno-Fierros L, AlpucheSolîs ÁG (2008) Ingestion of transgenic carrots expressing the Escherichia coli heat-labile enterotoxin $B$ subunit protects mice against cholera toxin challenge. Plant Cell Rep 27(1):79-84

Sambrook J, Russell DW (2006) Southern Blotting: Capillary Transfer of DNA to Membranes. Cold Spring Harbour Protocol, New York

Schonberger O, Hirst TR, Pines O (1991) Targeting and assembly of an oligomeric bacterial enterotoxoid in the endoplasmic reticulum of Saccharomyces cerevisiae. Mol Microbiol 5(11):2663-2671

Sim J-S, Pak H-K, Kim D-S, Lee S-B, Kim Y-H, Hahn B-S (2009) Expression and characterization of synthetic heat-labile enterotoxin B subunit and hemagglutinin-neuraminidase-neutralizing epitope fusion protein in Escherichia coli and tobacco chloroplasts. Plant Mol Biol Rep 27(3):388-399

Streatfield SJ, Jilka JM, Hood EE, Turner DD, Bailey MR, Mayor JM, Woodard SL, Beifuss KK, Horn ME, Delaney DE, Tizard IR, Howard JA (2001) Plant-based vaccines: unique advantages. Vaccine 19(17-19):2742-2748

Streatfield SJ, Mayor JM, Barker DK, Brooks C, Lamphear BJ, Woodard SL, Beifuss KK, Vicuna DV, Massey LA, Horn MA, Delaney DE, Nikolov ZL, Hood EE, Jilka JM, Howard JA (2002) Development of an edible subunit vaccine in corn against enterotoxigenic strains of Escherichia coli. Vitro Cell Dev Biol Plant 38(1):11-17

Sue MP, Mariana LF, Brian M, Linda MH (2005) Heterologous protein production using the Pichiapastoris expression system. Yeast 22(4):249-270

Svennerholm AM, Holmgren J, Black R, Levine M, Merson M (1983) Serologic differentiation between antitoxin responses to infection with Vibrio cholerae and enterotoxin-producing Escherichia coli. J Infect Dis 147(3):514-522

Svennerholm AM, Wikström M, Lindblad M, Holmgren J (1986) Monoclonal antibodies to Escherichia coli heat-labile enterotoxins: neutralising activity and differentiation of human and porcine LTs and cholera toxin. Med Biol 64(1):23-30

Tacket CO, Pasetti MF, Edelman R, Howard JA, Streatfield S (2004) Immunogenicity of recombinant LT-B delivered orally to humans in transgenic corn. Vaccine 22(31-32):4385-4389

Terpe K (2006) Overview of bacterial expression systems for heterologous protein production: from molecular and biochemical fundamentals to commercial systems. Appl Microbiol Biotechnol 72(2):211-222

Tingfeng L, Yuansheng Y, Say KN (2013) Advances in mammalian cell line development technologies for recombinant protein production. Pharmaceuticals 6(5):579-603

Tokuhara D, Yuki Y, Nochi T, Kodama T, Mejima M, Kurokawa S, Takahashi Y, Nanno M, Nakanishi U, Takaiwa F, Honda T, Kiyono H (2010) Secretory IgA-mediated protection against $V$. cholerae and heat-labile enterotoxin producing enterotoxigenic Escherichia coli by rice-based vaccine. Proc Natl Acad Sci U S A 107(19):8794-8799

Unni SC, Soniya EV (2010) Transgenic cucumis sativus expressing the hepatitis B surface antigen. Plant Mol Biol Rep 28(4):627-634

Williams NA, Hirst TR, Nashar TO (1999) Immune modulation by the cholera-like enterotoxins: from adjuvant to therapeutic. Immunol Today 20(2):95-101
Wurm FM (2004) Production of recombinant protein therapeutics in cultivated mammalian cells. Nat Biotechnol 22(11):1393-1398

Yang L, Wakasa Y, Takaiwa F (2008) Biopharming to increase bioactive peptides in rice seed. J AOAC Int 91(4):957-964

Yuki Y, Kiyono H (2009) Mucosal vaccines: novel advances in technology and delivery. Expert Rev Vaccines 8(8):1083-1097

Yuki Y, Mejima M, Kurokawa S, Hiroiwa T, Takahashi Y, Tokuhara D, Nochi T, Katakai Y, Kuroda M, Takeyama N, Kashima K, Abe M, Chen Y, Nakanishi U, Masumura T, Takeuchi Y, Kozuka-Hata H, Shibata H, Oyama M, Tanaka K, Kiyono H (2013) Induction of toxin-specific neutralizing immunity by molecularly uniform rice-based oral cholera toxin B subunit vaccine without plant-associated sugar modification. Plant Biotechnol J 11(7):799-808

\section{Submit your manuscript to a SpringerOpen ${ }^{\circ}$ journal and benefit from:}

- Convenient online submission

- Rigorous peer review

- Immediate publication on acceptance

- Open access: articles freely available online

- High visibility within the field

- Retaining the copyright to your article

Submit your next manuscript at $>$ springeropen.com 